\title{
Quaternary deposits and weathered bedrock material as a source of dangerous radon emissions in Estonia
}

\author{
Valter Petersell ${ }^{1}$, Krista Jüriado ${ }^{2 *}$, Anto Raukas ${ }^{3}$, Mihkel Shtokalenko ${ }^{1}$, Krista \\ Täht-Kok ${ }^{1}$
}

\author{
${ }^{1}$ Geological Survey of Estonia, Kadaka tee 82, 12618 Tallinn, Estonia \\ e-mail: v.petersell@egk.ee \\ ${ }^{2}$ Tallinn University, Narva mnt 25, 10120 Tallinn, Estonia \\ *Corresponding author, e-mail: krista.juriado@gmail.com \\ ${ }^{3}$ Institute of Ecology at Tallinn University, Uus-Sadama 5, 10120 Tallinn, Estonia \\ e-mail: anto.raukas@mail.ee
}

\begin{abstract}
The risk of dangerous radon emissions in Estonia is high, being among the highest in Europe. In almost 33 per cent of Estonian land area, the content of radon in soil-contained air exceeds the safe limit for unrestricted construction (50 $\mathrm{kBq} / \mathrm{m}^{3}$ ). In such high radon-risk areas the concentration of radon in soil-contained air ranges from 50 to $400 \mathrm{kBq} / \mathrm{m}^{3}$, in a few cases reaching up to $2,100 \mathrm{kBq} / \mathrm{m}^{3}$ exceeding the permitted level for residential areas. The situation is particularly serious in the northernmost part of the country, where uranium-rich graptolite argillite (Dictyonema shale) and the Obolus phosphorite are close to ground surface and their particles are constituent parts of Quaternary deposits. Radon emissions from bedrock have been investigated in detail, but to date Quaternary strata as a source of radon emissions are poorly studied. According to our measurements the highest concentrations of radon are related to tills containing clasts and fines of graptolite argillite and phosphorite. Glacial deposits include also granitoidal material, containing U, Th and K, which have been transported by glaciers from the outcrop areas of crystalline basement rocks in Finland and the Gulf of Finland. Due to weathering, outwash and repeated redeposition other genetic types are poorer in radioactive elements and they are weaker sources of radon.
\end{abstract}

Keywords: radon, uranium, klint, graptolite argillite, Quaternary deposits, till

\section{Introduction}

The focus of the present paper is on $\mathrm{Rn}-222$, a radon decay chain $\mathrm{U}-238$ isotope that is responsible for more than 93 per cent of radiation caused by radon (UNSCEAR, 1993). Radon is a source of natural ionising radiation; it is a toxic element causing mutations, primarily lung cancer (World Health Organization, 2009). Health effects of radon are actually due to inhalation of its decay products; but, in general, they are referred to as radon health effects (Bochicchio, 2005). The first radon surveys in Estonia were carried out by the Department of Building Physics at the Estonian Building Research
Institute (EBRI) during 1989-1991 (Pahapill et al., 1993). The Estonian Geological Survey, in co-operation with the Estonian Radiation Centre and the Swedish Radiation Protection Institute, discovered that the indoor air of about one third of individual dwellings contains high levels of radon. It often exceeds the permissible level $\left(200 \mathrm{~Bq} / \mathrm{m}^{3}\right)$ (Estonian Centre for Standardisation, 2009) and reaches 3,000 $\mathrm{Bq} / \mathrm{m}^{3}$, sometimes even $10,000 \mathrm{~Bq} / \mathrm{m}^{3}$ (Pahapill et al., 2003). In 33 per cent of Estonian land area the content of radon in soil air is also high and exceeds the safe limit for unrestricted construction $(50 \mathrm{kBq} /$ $\mathrm{m}^{3}$ ) (Estonian Centre for Standardisation, 2009). In such high radon-risk areas the concentration of ra- 
don in soil air ranges from 50 to $400 \mathrm{kBq} / \mathrm{m}^{3}$, in few cases reaching 2,100 kBq/ $\mathrm{m}^{3}$. Petersell et al. (2013) showed that the areas with high indoor air radon activity concentration in buildings overlap with the areas of high soil gas radon activity concentration and are closely connected to soils which are rich of the graptolite argillite (Dictyonema shale) (uranium content up to $300 \mathrm{mg} / \mathrm{kg}$ ) and phosphorite (uranium content up to $40 \mathrm{mg} / \mathrm{kg}$ ) particles.

A similar situation is seen in alum shale areas in Sweden (Västergötland, Storsjön Area, Billingen and elsewhere), where the uranium content reaches $300 \mathrm{mg} / \mathrm{kg}$ (Andersson et al., 1985) and radon content in the near surface air up to $1,000 \mathrm{kBq} / \mathrm{m}^{3}$ (Clavensjö \& Åkerblom, 1994).

At the same time rather high radon concentrations have been observed all over Estonia and this triggered us into studying different genetic types of Quaternary deposits as the possible sources of radon emissions. The lithology and mineralogy of Estonian Quaternary deposits have been studied in detail (see, among other, Raukas, 1978), but in the Soviet time the study of radioactivity and radon emissions was not recommended and publication of materials was restricted. For example, only recently have we been able to publish materials about the close relationships of heavy minerals and radioactivity of coastal sediments in the example of the Lemme area (Raukas et al., 2014), a region already studied during the 1960s (Kessel \& Raukas, 1967).

Using data from 566 observation points, the first radon-risk map of Estonian soil was compiled ten years ago by the Geological Survey of Estonia in co-operation with the Swedish Radiation Protection Institute, the Geological Survey of Sweden and the Estonian Radiation Centre (Petersell et al., 2005). During the last decade an abundant new factual material (about 480 observation points) was collected by ourselves (Petersell et al., 2006; Petersell et al., 2008; Jüriado \& Petersell, 2010; Jüriado et al., 2012; Raukas et al., 2014) and added to our new map, compiled by M. Shtokalenko, under the supervision of V. Petersell.

\section{Geological setting and former geological studies}

Estonia is located in the northwestern part of the Eastern European Craton. Structurally it lies mainly within the boundaries of the southern slope of the Fennoscandian (Baltic) Shield or Estonian monocline, with only its extreme southeastern and southwestern parts as the northern limbs of the
Baltic Synecline and Valmiera-Lokno Anticline, respectively. The depth to the crystalline basement ranges from $100 \mathrm{~m}$ in North Estonia to $600 \mathrm{~m}$ in the south-eastern part of the country. The rugged and weathered crystalline basement rocks are overlain by Vendian and Cambrian sandstones, siltstones and clays, Ordovician and Silurian limestones, dolostones and marls, and reddish-brown Devonian sand- and siltstones. In North Estonia the bedrock consists of carbonaceous rocks, whilst in South Estonia terrigenous rocks predominate.

The Estonian topography is mostly flat, the southeast of the country being hilly. The westeast oriented North Estonian Klint ${ }^{1}$, up to $55.6 \mathrm{~m}$ in height (Suuroja, 2006), and deep ancient valleys cutting into the sedimentary bedrock (Miidel et al., 2006; Raukas \& Tavast, 1987; Vaher et al., 2010) are the most remarkable elements of the bedrock.

The classification and genesis of Quaternary deposits is a complex problem and a huge success in this field was gained by the INQUA Commission on Genesis and Lithology of Quaternary deposits. This important project was initiated at Poznan University by the Co-President of the Commission, Professor B. Krygowski, in the autumn of 1967. The main focus was on tills; in Poland several international conferences were organised on that topic (e.g., in 1969 and 1975). In September 1975 a panel discussion on "Investigation methods of tills and the possibilities of their unification" was staged and later summarised by W. Stankowski (1976).

In 1974 A. Raukas, E. Rähni and K. Vares compiled a map of soil-forming rocks of Estonia and calculated the area of distribution of different genetic types of Quaternary deposits according to the administrative regionalisation of the former Soviet state of Estonia (Table 1). All deposits were divided into glacial, fluvial, aeolian, gravitational and organogenic rows with thirteen genetic groups (Vares \& Raukas, 1981).

The term klint, widely used in countries around the Baltic Sea, was originally a Danish and Swedish word synonymous with klev, signifying an escarpment in sedimentary rocks. Usually it comprises a line of marine abrasion or ancient (pre-Quaternary) fluviatile erosion scarps. In the German literature the word glint is preferred; in English it is often recorded as clint. The best-known klint in the Baltic Sea area is the Ordovician, near-continuous arc along the western coast of the Island of Öland (Sweden) via the north coast of Estonia to Lake Ladoga in Russia.The term klint is used increasingly also in North America and western Europe in reference to steep escarpments of sedimentary rocks with monoclinal bedding. 
Table 1. Distribution of different soil-forming rocks in former Soviet Estonia, in percentages (Vares \& Raukas, 1981).

\begin{tabular}{lrrrr}
$\begin{array}{l}\text { Administrative } \\
\text { region }\end{array}$ & Till & fgl* & lgl** & $\begin{array}{c}\text { Remain- } \\
\text { ders }\end{array}$ \\
\hline Hiiumaa & 19.8 & - & 29.5 & 50.7 \\
Kingissepa & 76.2 & 3.2 & 10.3 & 10.3 \\
Haapsalu & 38.5 & 3.2 & 20.0 & 38.3 \\
Harju & 44.8 & 4.5 & 1.5 & 49.2 \\
Rakvere & 70.4 & 1.2 & 0.8 & 27.6 \\
Kohtla-Järve & 37.1 & 3.1 & 3.1 & 56.7 \\
Rapla & 40.2 & 5.7 & 12.6 & 41.5 \\
Paide & 55.6 & 0.4 & - & 44.0 \\
Jõgeva & 67.2 & 0.3 & 3.2 & 29.3 \\
Pärnu & 31.5 & 2.8 & 14.0 & 51.7 \\
Viljandi & 61.8 & 0.5 & 3.1 & 34.6 \\
Tartu & 54.6 & 0.1 & 3.7 & 41.6 \\
Põlva & 43.7 & 3.4 & 0.4 & 52.5 \\
Valga & 39.2 & 6.6 & 0.1 & 54.1 \\
Võru & 35.6 & 12.0 & 0.1 & 52.3 \\
Whole Estonia & 47.7 & 3.1 & 6.8 & 42.3 \\
\hline
\end{tabular}

*fgl - glaciofluvial deposits; ** $\operatorname{lgl}$ - glaciolacustrine deposits.

About 95 per cent of the Quaternary sequence comprises glacial and glacial meltwater deposits (Raukas, 1978). Of these, glacial deposits comprise 70 per cent of the volume and 47.7 per cent of the land area. Glaciolacustrine (6.8 per cent of area) and glaciofluvial (3.1 per cent) deposits are also widely distributed. Five till units, often of great thickness, are distinguished (Raukas 1978, 1995).

In Table 1, in the column "Remainders", the most important is peat (22.3 per cent of the Estonian territory is covered with wetlands) and in Lower Estonia coastal deposits of different stages of the Baltic Sea have a wide distribution. Technogenous deposits cover about 2 per cent of Estonian territory, while fluvial, aeolian and slope deposits are distributed sporadically. Due to weathering, multiple displacement and outwash of glacial and glacial-meltwater deposits, marine and aeolian deposits are more or less mono-mineral (enriched in quartz) and therefore have low radon emissions.

\section{Composition and natural radioactivity of glacial and glaciogenic deposits}

As mentioned above, our main interest was the sampling of tills which illustrate well how closely the granulometric, lithological, mineralogical and chemical composition, plus colouring, of the tills were linked to the character of the underlying bedrock along which the continental ice sheet moved (Raukas, 1969, 1978; Raukas \& Gaigalas, 1993). Thus, in the fore-klint zone, on the Cambrian blue clays and on the light-coloured sand- and siltstones, the till of the last glaciation is of a greenish-grey or bluish grey colour, and its fine fraction comprises clay or loam. In the pebble and gravel fractions of this till, carbonaceous rocks generally are missing, the clasts in this till being represented by magmatic, metamorphic and Cambrian sedimentary rocks, including high concentrations of graptolite argillite particles. For example, at Maardu, it attains 12-34 per cent (maximum 73.5 per cent) in the fraction 10-5 mm (Raukas, 1961a), causing high radioactivity and marked radon risks (Jüriado et al., 2012). The mineral composition of the sandy and silty fractions in these tills is characterised by a comparatively high content of heavy minerals, and of pyrite in particular (25-51 per cent in the heavy subfraction), and by a low carbonate content (0.5-15.5 per cent) (Raukas, $1969,1978)$. In comparison with the other varieties, the grey-coloured tills on carbonaceous bedrock contain a greater amount of coarse fractions, mainly carbonates (over 60 per cent in 80 per cent of cases, and over 80 per cent in 68 per cent of cases). The effect of the underlying carbonaceous rocks is also reflected in the mineral composition. Thus, the content of calcite and dolomite in the sandy fraction of the North Estonian tills usually varies between 20 and 70 per cent (Raukas, 1969, 1978).

Tills on Devonian bedrock have a reddish-brown colour and the coarse fraction content is low. In comparison with the North Estonian tills we see here a decrease of carbonate clasts, which are less resistant than magmatic and metamorphic rocks. In the sandy and silty fractions among the heavy subfraction a significant role is played by minerals typical of the underlying Devonian rocks (zircon, monazite, tourmaline, garnets, and others). As a rule, the content of carbonate minerals in the sandy fractions does not exceed 10 per cent (Raukas, 1961b).

Estonia belongs to the zone of glacial erosion or moderate accumulation, and, therefore the Quaternary cover is rather thin, in northern Estonia usually less than 5 metres. The cover is thickest in the Haanja and Otepää heights in southeast Estonia (often in excess of $100 \mathrm{~m}$ ) and in the buried valleys of southern Estonia (at Keskküla 207 m). Numerous investigations have demonstrated that, during flow, the ice sheets incorporated local bedrock material depending of underlying topography and dynamics of ice movement. The transport distance of clasts greatly depends of the composition and size of erratics. Argillites and weakly cemented sandstone clasts may 
have travelled no more than $15 \mathrm{~km}$, but the crystalline rocks and dolostones have been transported over hundreds of kilometres (Raukas, 1995). In southern Estonia high radioactivity depends of Devonian bedrock containing uranium-rich minerals (zircone, monazite) and erratic boulders in till with high radioactivity. For example, the granites of the rapakivi formation cropping out on the bottom of the Gulf of Finland and in southern Finland contain 3-10 g/t of U, 10-50 g/t of Th and 2.2-3.5 per cent of K (Koljonen, 1992).

Glaciofluvial deposits in their main part are characterised by a great variety in granulometric composition and structure, as well as in lithological and mineralogical composition, closely linked everywhere to the composition of adjacent till and bedrock. In the course of formation of glaciofluvial deposits, the content of resistant rocks and minerals increases on account of less stable fractions that are crushed and destroyed during their transportation by water streams. Usually the content of crystalline rocks in gravel-and-pebble fractions of glaciofluvial deposits is $10-15$ per cent higher than in tills (Raukas, 1978).

Glaciolacustrine deposits, predominantly varved clays, contain mainly dioctahedral hydromicas and mixed-layered formations (55-75 per cent) in clay fractions, also kaolinite (15-25 per cent), chlorites (5-10 per cent), various terrigenous minerals (up to 10 per cent), amorphous silica (0.5-1.5 per cent) and several hydrous ferric oxides (1.5-3 per cent) are to be observed. The mineral composition of clay fractions (less than a micron in size) of varved clays is also similar to adjacent tills. This similarity and the high content of weathering-resistant minerals in clays points to the insignificant role of chemical changes in the transformation of the initial morainic material into glaciolacustrine clay.

\section{Methods}

Fieldwork was based on methods developed in Sweden and adapted to conditions prevailing in Estonia (Petersell et al., 2005). The position of investigation sites was determined within a circle of c. $200 \mathrm{~m}$ in diameter, considering that the ground surface should be flat, without any visible evidence of technogeneous contamination, and the gamma radiation level (determined with $\mathrm{CP}-88 \mathrm{H}$ ) should be typical of the area. At these sites, radon activity concentration $\left(\mathrm{kBq} / \mathrm{m}^{3}\right)$ in soil-contained air was measured at a depth of $80 \mathrm{~cm}$ using Markus 10 emanometer (RnM), and calculated (RnG) using measurements from the bottom of the excavation at the same point with a gamma ray spectrometer that measured ${ }^{226} \mathrm{Ra}$ or Ra balanced with ${ }^{238} \mathrm{U}(\mathrm{eU})$ content (Petersell et al., 2005). RnM and RnG are not comparable; they do not correlate and their sources are different. RnG characterises the radon risk level in the almost 2-m-thick layer of Quaternary sediments in the mainland as a whole, and forms an individual unity. RnM concentration is generally lower than RnG, temporally very variable and dependent of atmospheric conditions. A higher level of RnM is found only in areas where there are deeper-lying bedrock varieties with high eU concentration, from the surface down to depths of 200-300 m (Petersell et al., 2005).

In addition, ${ }^{232} \mathrm{Th}$ or eTh and ${ }^{40} \mathrm{~K}$ balanced with $\mathrm{K}$ or eK content in the soil was measured. These data enable us to obtain a picture of the formation of thorium, a radioactive decay chain of ${ }^{220} \mathrm{Rn}$ or thoron in soil-contained air, if necessary, and to calculate the level of natural radiation. $80 \mathrm{~cm}$ is considered to be an optimal depth. On the one hand, the measurements are taken from a relatively slightly weathered Quaternary deposit; on the other hand, the level of groundwater in areas of Estonia suitable for building houses usually is deeper than $80 \mathrm{~cm}$.

Genetic types of the Quaternary deposits were determined and soil samples of about $6 \mathrm{~kg}$ were taken from the bottom of the excavation so as to check at the laboratory the concentrations of $\mathrm{U}$, Th, $\mathrm{K}$ and eU, eTk and ${ }^{40} \mathrm{~K}(\mathrm{~K})$. The following main types of Quaternary deposits were established: North Estonian grey till (mp), South Estonian reddish-brown till $(\mathrm{ml})$, glaciofluvial (fgl), glaciolacustrine (sand - lgl, silt - lga and clay - lgs) and Baltic Sea deposits (sand and silt $-b$ ), as well as klint slope (kla) and technogeneous ( $\mathrm{t}$ ) deposits.

In order to check the reliability of the results, measuring was repeated during field work using both the same and parallel equipment. Parallel measurements were done at every tenth point using the other gamma spectrometer. Based on the eU concentration measured with this device, the concentration of radon in soil-contained air was calculated according to the following formula:

$$
\begin{gathered}
\mathrm{RnG}=\mathrm{A} \cdot \mathrm{e} \cdot \sigma \cdot(1-\mathrm{p}) \mathrm{p}^{-1} \\
\text { (Clavensjö \& Akerblom, 1994), }
\end{gathered}
$$

where:

$\mathrm{RnG}$ - radon maximum content developed, $\mathrm{Bq} / \mathrm{m}^{3}$;

$\mathrm{A}-\mathrm{eU}$ concentration, $\mathrm{Bq} / \mathrm{kg}$;

e - radon emanation factor;

б - compact volume weight (specific weight), $\mathrm{kg} /$

$\mathrm{m}^{3}$;

$\mathrm{p}$ - porosity. 
(1 mg/kg eU = 12.35 Bq/kg; Åkerblom, 1994)

Based on depth, soil type and radon diffusion dependence graph (Clavensjö \& Åkerblom, 1994), the results of directly measured radon concentrations were re-calculated to a standard depth of $1 \mathrm{~m}$.

The soil samples collected at the bottom of excavation points were dried and separated into two equal parts. The first part was sent to the laboratory of the Estonian Radiation Centre to determine the concentration of eU, eTh and ${ }^{40} \mathrm{~K}(\mathrm{~K})$; the second part, a $<2 \mathrm{~mm}$ fraction, was powdered, quartered and sent to the AcmeLabs in Canada, where the concentrations of $\mathrm{U}$, Th and $\mathrm{K}$ and accompanying elements were measured.

In the area investigated, the dispersion of the measured elements was very high and changeable and their distribution was subjected to log-normal (geometrical) distribution principles. As a result, the geometric mean concentration and standard deviation were used.

\section{Results and discussion}

Different authors have assessed the average concentration of $U$ in the upper part of the Earth's crust to be $2.5 \mathrm{ppm}$ (Wedepohl, 1995), the average level of Ra being about $1 \cdot 10^{-10}$ per cent (Ivanov, 1994). However, there is no consensus on the average level of $\mathrm{eU}$. According to preliminary data, concentration of both $\mathrm{U}$ and $\mathrm{eU}$ in the top 2-metre layer of Estonian Quaternary deposits is similar, c. $2.1 \mathrm{ppm}$. The variation in concentrations is high and maximum concentrations reach 54 ppm (Petersell et al., 2005).

Although, the ratio of radium and radon in the soil, generated during its radioactive decay, is constant, the preservation of generated radon in soil-contained air in the natural environment is not the norm. The emission of radon from soil to the atmosphere is changeable due to ubiquitous aeration of the soil (Clavensjö \& Akerblom, 1994). During a survey with Athmos 12DPXS, a short-term (three hours) measurement demonstrated that $0.5-1 \mathrm{~m}$ above the ground, the radon content in the air reaches up to $100 \mathrm{~Bq} / \mathrm{m}^{3}$ in high radon-risk areas, and up to $400 \mathrm{~Bq} / \mathrm{m}^{3}$ in areas with very high radon-risk (content of RnG in the soil air $>250 \mathrm{kBq} / \mathrm{m}^{3}$ ). In Estonia, the radon level retained in soil-contained air is up to twice (or more) lower in the dry summer period than in the winter in case of watering of top soil and frozen ground (Jüriado et al., 2014). The correlation between $\mathrm{U}$ and $\mathrm{Ra}-226$ is not always

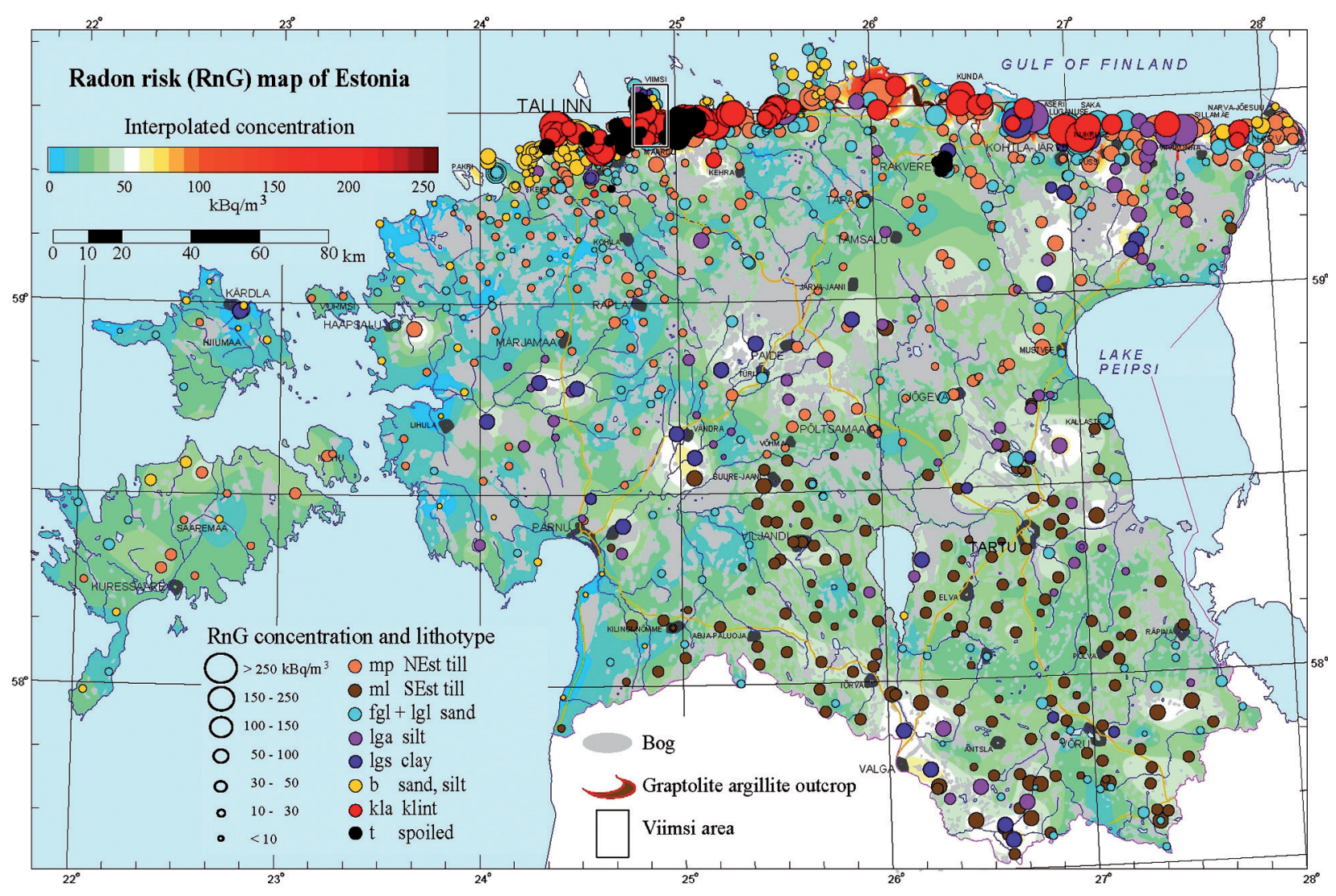

Fig. 1. Radon risk map of Estonia, with the Viimsi area (see Fig. 2) marked (map compiled by M. Shtokalenko, under the supervision of V. Petersell). 
clear either. It is likely that in many areas, $\mathrm{U}$ has been washed out and piled in nearby deposits in relation to Ra-226. For example, in southern Estonia, the Mustjõe River fen peat ash (ash content 40-50 per cent) contains $50-100 \mathrm{mg} / \mathrm{kg}$ of $\mathrm{U}$ according to the X-ray fluorescence method. The eU content of the same peat measured with a gamma ray spectrometer, however, is $<3 \mathrm{mg} / \mathrm{kg}$. A similar phenomenon can be observed in other Estonian wetlands (Kiipli, 2005).

Due to aeration, radon content in soil-contained air determined from eU content is always greater than $\mathrm{RnM}$ content retained in soil-contained air that can be measured during direct measuring. The less clay the soil contains, being drier and more porous, the more radon aerates into air and less of it is retained in the soil as a result of a decay of radium. The amount of radon retained in the soil-contained air can be more than three times smaller than originally developed. While underneath buildings, aeration of the soil decreases until being eliminated, radon content approaches the content calculated from eU content. However, radon retained in soil-contained air could be supplemented by radon moving towards lower pressure from deeper radon-rich Quaternary deposits and bedrock. The migration of the latter is encouraged substantially by geogases and crevices in the bedrock. This can happen in Quaternary deposits along the borders of an ancient valley, first and foremost in the klint zone of northern Estonia, where ancient valleys are filled with glacial deposits of sand and silt as a result of the development of the Baltic Sea. Based on available data, their radon content in the soil-contained air remains similar to the content calculated from the eU content. For that reason, the map of radon content in the pores of Quaternary deposits (Fig. 1) has been compiled based on the radium content measured in about $80-\mathrm{cm}$-deep deposits. This characterises the radon-risk level of the upper 1.5-2 metres of soil. Migration of deeper radon is not reflected on the map. A new map compiled by using data from 1,046 observation points (566 from early observations and 480 from new data) shows large differences in regional distribution.

The analysis of our Radon-risk map shows that the level of radon risk in Estonian soils varies widely. The highest risk is connected to the klint zone between Narva and Islands of Pakri (Fig. 1). Near Sillamäe, Aseri, Saka, Kunda, Maardu and Viimsi

Table 2. Content of calculated radon $(\mathrm{RnG})$ and eU in the main Estonian Quaternary lithotypes: $\mathrm{n}$ - number of observation points; $x_{\min }$ and $x_{\max }$ - minimum and maximum content; $x_{a}$ and $x_{g}$ - arithmetic and geometric mean in soil-contained air content; $s$ and $s_{g}$ - standard deviation and standard deviation as coefficient.

\begin{tabular}{|c|c|c|c|c|c|c|c|}
\hline Lithotype & $\mathrm{n}$ & $x_{\min }$ & $\mathrm{x}_{\max }$ & $x_{a}$ & $\mathrm{~s}$ & $x_{g}$ & $\mathrm{~s}_{\mathrm{g}}$ \\
\hline \multicolumn{8}{|c|}{$\mathrm{RnG}\left[\mathrm{kBq} / \mathrm{m}^{3}\right]$} \\
\hline Sand, silt and gravel of the Baltic Sea deposits (b) & 145 & 1.0 & 184.0 & 36.50 & 38.43 & 23.62 & 2.63 \\
\hline Glaciolacustrine sand and gravel (lgl) & 148 & 1.0 & 283.0 & 47.07 & 51.91 & 30.74 & 2.48 \\
\hline Glaciolacustrine silt (lga) & 85 & 8.0 & 608.0 & 58.43 & 84.00 & 41.15 & 2.03 \\
\hline Glaciolacustrine clay (lgs) & 33 & 24.0 & 1801.8 & 113.08 & 304.52 & 62.19 & 2.02 \\
\hline Glaciofluvial deposits (fgl) & 85 & 2.8 & 159.0 & 35.99 & 34.91 & 24.79 & 2.36 \\
\hline North- Estonian till (mp) & 290 & 0.9 & 524.1 & 50.12 & 56.33 & 34.79 & 2.27 \\
\hline South -Estonian till (ml) & 159 & 9.0 & 69.3 & 36.07 & 10.74 & 34.37 & 1.39 \\
\hline Fore-klint and klint slope deposits (kla) & 64 & 22.1 & 824.8 & 178.77 & 134.24 & 143.23 & 1.96 \\
\hline Technogenous deposits $(\mathrm{t})$ & 42 & 17.0 & 381.6 & 75.16 & 72.02 & 57.80 & 1.94 \\
\hline All together & 1054 & 0.9 & 1801.8 & 56.69 & 87.61 & 36.33 & 2.43 \\
\hline \multicolumn{8}{|c|}{$\mathrm{eU}$ [ppm] } \\
\hline Sand, silt and gravel of the Baltic Sea deposits (b) & 145 & 0.07 & 12.40 & 2.50 & 2.60 & 1.60 & 2.69 \\
\hline Glaciolacustrine sand and gravel (lgl) & 148 & 0.07 & 18.60 & 3.12 & 3.49 & 2.03 & 2.47 \\
\hline Glaciolacustrine silt (lga) & 85 & 0.50 & 46.40 & 3.64 & 5.88 & 2.49 & 2.05 \\
\hline Glaciolacustrine clay (lgs) & 33 & 1.40 & $106.0^{*}$ & 6.62 & 17.92 & 3.62 & 2.03 \\
\hline Glaciofluvial deposits (fgl) & 85 & 0.20 & 17.30 & 2.63 & 2.98 & 1.73 & 2.42 \\
\hline North-Estonian till (mp) & 290 & 0.07 & 37.25 & 3.51 & 3.93 & 2.44 & 2.26 \\
\hline South-Estonian till (ml) & 159 & 0.60 & 14.60 & 2.29 & 1.19 & 2.14 & 1.43 \\
\hline Fore-klint and klint slope deposits (kla) & 64 & 1.50 & 53.95 & 11.91 & 8.99 & 9.53 & 1.96 \\
\hline Technogenous deposits $(\mathrm{t})$ & 42 & 1.32 & 24.70 & 4.83 & 4.69 & 3.69 & 1.95 \\
\hline All together & 1054 & 0.07 & 106.00 & 3.80 & 5.79 & 2.41 & 2.44 \\
\hline
\end{tabular}

* on the graptolite argillite lying clay. 


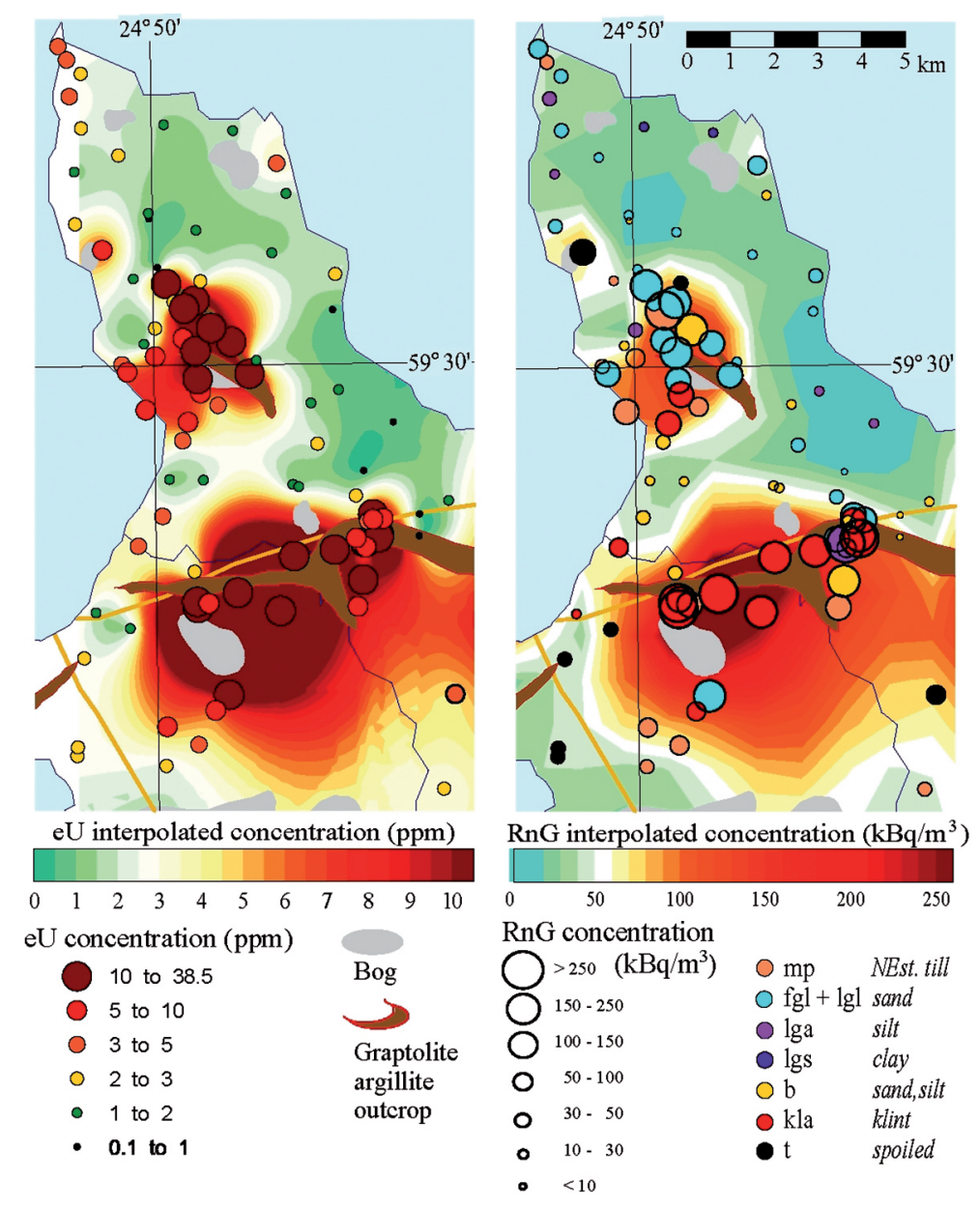

Fig. 2. eU and radon content in the Viimsi area (cutoff map of radon-risk map showing eU and radon content in Viimsi highrisk area; map compiled by M. Shtokalenko, under the supervision of V. Petersell and K. Jüriado).

(Fig. 2), in all lithotypes (excluding contemporary coastal deposits) the content of RnG often exceeds $250 \mathrm{kBq} / \mathrm{m}^{3}$ and reaches in the slope deposits of the klint up to $825 \mathrm{kBq} / \mathrm{m}^{3}$ and in glaciolacustrine graptolite rich clay in extreme cases up to 1801.8 $\mathrm{kBq} / \mathrm{m}^{3}$ (Table 2 ). Areas with very high radon risk are connected to outcrops of graptolite argillite and phosphorite.

To the west of Kohtla-Järve, in the Lüganuse area, some $10 \mathrm{~km}$ to the south from the klint a 5-7$\mathrm{km}$ wide outcrop of till with a high radon risk (up to $280 \mathrm{kBq} / \mathrm{m}^{3}$ ) is registered. Till with high radon risk is exposed also in central Estonia, in the Suure-Jaani -Vändra-Türi area.

In south Estonia the radon risk is lower, but in the vicinity of Võru and Valga in large areas the radon content in soil-contained air often is over 50 $\mathrm{kBq} / \mathrm{m}^{3}$ (up to $69 \mathrm{kBq} / \mathrm{m}^{3}$ ). Additionally, up to 200 $\mathrm{kBq} / \mathrm{m}^{3}$ radon will migrate from Devonian bedrock in the area (Petersell et al., 2005).

The thickness of the high radon risk deposits often exceeds 2 metres and reaches 100 metres and more in ancient valleys. In these areas, the radon risk level may increase due to additional radon inflow from deeper soils. Karst areas, where RnG content reaches $120 \mathrm{kBq} / \mathrm{m}^{3}$ (for example in Uhaku karst field) in residual soil, also have high risk in places. At times, the RnM content exceeds the RnG content in these areas. The Maardu phosphorite quarry spoil heaps stand out as very high radon risk area. The RnG content in soil-contained air varies from 134 to $382 \mathrm{kBq} / \mathrm{m}^{3}$ there, while due to soil aeration, the RnM content is low and homogeneous, varying between 25 and $34 \mathrm{kBq} / \mathrm{m}^{3}$.

\section{Conclusions}

The analysis of our radon risk map (Fig. 1) and the composition of different genetic types of Quaternary deposits show that the radon risk level in Estonian soils varies widely in all lithotypes, reaching $1801.8 \mathrm{kBq} / \mathrm{m}^{3}$ (Table 2). Areas with high radon risk appear directly in graptolite argillite and phosphorite outcrops and also in a number of places on till. Klint slope deposits between Narva and Islands of Pakri and technogenous deposits in several places in northern Estonia (for example at Viimsi, Maardu and Tallinn) often contain graptolite argillite and Obolus phosphorite specks; these are 
dangerous areas as well. Measures to minimise the radon risk need to be implemented in areas where the radon content in soil-contained air exceeds 50 $\mathrm{kBq} / \mathrm{m}^{3}$. These are known as high radon risk areas. As shown on the radon risk map, areas with high radon risk hazardous to human health can be found all over Estonian territory, but most of them are located in the north Estonian klint zone. There the radon content in soil-contained air exceeds the quota set for building without restrictions $(50 \mathrm{kBq} /$ $\mathrm{m}^{3}$ ) ten or more times. The RnG content in soil-contained air outside of klint zone exceeds quota up to 1.5 times, sometimes up to 2 times. Our work enables to predict radon sources and dangerous areas.

\section{Acknowledgements}

The authors express their gratitude to the reviewers for useful comments and remarks made on the manuscript.

\section{References}

Andersson, A., Dahlman, D., Gee, D.G. \& Snäll, S., 1985. The Scandinavian alum shales. Sveriges Geologiska Undersökning Ca 56, 1-50.

Åkerblom, G., 1994. Ground radon - monitoring procedures in Sweden. Geoscientist 4, 21-27.

Bochicchio, F., 2005. Radon epidemiology and nuclear track detectors: Methods, results and perspectives. Radiation Measurements 40, 177-190.

Clavensjö, B. \& Åkerblom, G., 1994. The Radon book. Measures against radon. The Swedish Council for Building Research, Stockholm, 129 pp.

Estonian Centre for Standardisation, 2009. Estonian Standard 840:2009. Design of Radon-Safe Buildings. Estonian Centre for Standardisation, $20 \mathrm{pp}$. [in Estonian].

Ivanov, V.V., 1994. Èkologičeskaja geohimija èlementov. Kniga 1. Spravochnik [Ecological geochemistry of elements]. Èkologija, Moskva, 305 pp. [in Russian].

Jüriado, K. \& Petersell, V., 2010. Relationship between the concentration of radon directly measured in soil air and calculated after radium. [In:] I. Barnet, M. Neznal \& P. Pacherová (Eds): 10th International Workshop on the Geological Aspects of Radon Risk Mapping. Czech Geological Survey, Prague, 148-156.

Jüriado, K., Petersell, V. \& Raukas, A., 2014. Seasonal variations of radon concentration in soil air in different geological conditions on the example of Estonia. Geologija 56, 4, 87-97.

Jüriado, K., Raukas, A. \& Petersell, V., 2012. Alum shales causing radon risks on the example of Maardu area, North Estonia. Oil Shale 29, 76-84.

Kessel, H.J. \& Raukas, A., 1967. The deposits of the Ancylus Lake and Littorina Sea in Estonia. Valgus, Tallinn, 135 pp. [in Russian, with English summary].
Kiipli, T., 2005. Biogeokeemiline uuring Viljandi ja Tartu piirkonnas [Biogeochemical study in Viljandi and Tartu regions]. [In:] M. Kukk (Ed.): Eesti Geoloogiakeskuse aastaraamat 2004 [Annual of the Geological Survey of Estonia 2004]. Geological Survey of Estonia, Tallinn, 30-33.

Koljonen, T. (Ed.), 1992. The Geochemical Atlas of Finland. Part 2. Till. Geological Survey of Finland, Espoo, 218 pp.

Miidel, A., Raukas, A., Tavast, E. \& Vaher, R., 2006. Influence of bedrock topography on oil shale mining in North-East Estonia. Oil Shale 23, 313-327.

Pahapill, L., Jõgioja, E. \& Rohumäe, T., 1993. Indoor radon in Estonia. International Conference on Indoor Air Quality and Climate 4, 471-474.

Pahapill, L., Rulkov, A., Rajamäe, R. \& Åkerblom, G., 2003. Radon in Estonian Dwellings. Results from a National Radon Survey. SSI raport: 2003:16. Swedish Radiation Protection Authority, Estonian Radiation Protection Centre, Stockholm, 20 pp.

Petersell, V., Mõttus, V. \& Täht, K., 2006. Ida-Virumaa radooniriski kaart, M 1:200000 [Radon Risk Map of Ida-Virumaa at scale of 1:200000]. Geological Survey of Estonia, Tallinn, 29 pp. [in Estonian].

Petersell, V., Täht-Kok. K. \& Karimov, M., 2008. Harjumaa radooniriski kaart, M. 1:200000 [Radon Risk Map of Harjumaa at scale of 1:200000]. Geological Survey of Estonia, Tallinn [in Estonian].

Petersell, V., Shtokalenko, M., Täht-Kok, K. \& Talpas, A., 2013. Kirde-Eesti tööstuspiirkonna pinnase (muldade) keskkonnaseisundi uuringute aruanne [Report of the study of environmental condition of soils in the industrial area of north-eastern Estonia]. Geological Survey of Estonia, Tallinn, 111 pp. [in Estonian].

Petersell, V., Åkerblom, G., Ek, B.-M., Enel, M., Mõttus, V. \& Täht, K., 2005. Radon Risk Map of Estonia: Explanatory text to the Radon Risk Map Set of Estonia at scale of 1:500 000 Report 2005:16. Swedish Radiation Protection Authority, Tallinn, $76 \mathrm{pp}$.

Raukas, A., 1961a. Mineraloogilise meetodi kasutamise võimalusest moreenide uurimisel Eestis [Application of the mineralogical method to the investigation of tills in Estonia]. ENSV Teaduste Akadeemia Geoloogia Instituudi Uurimused. Antropogeeni geoloogia 7, 55-67 [in Estonian with Russian and English summaries].

Raukas, A., 1961b. Mineralogia moren Estonii [The mineralogy of the Estonian tills]. Eesti NSV Teaduste Akadeemia Toimetised. Fü̈sikalis-matemaatiliste ja tehniliste teaduste seeria 10, 3, 244-258 [in Russian with English summary].

Raukas, A., 1969. Composition and genesis of Estonian tills. Uniwersytet im. Adama Mickiewicza w Poznaniu. Seria Geografia 8, 167-176.

Raukas, A., 1978. Pleistotsenovye otloženia Estonskoi SSR [Pleistocene deposits of the Estonian SSR]. Valgus, Tallinn, 310 pp. [in Russian with English summary].

Raukas, A., 1995. Properties, origin and stratigraphy of Estonian tills. [In:] J. Ehlers, S. Kozarski \& P.L. Gibbard (Eds): Glacial deposits in North-East Europe, Balkema, Rotterdam, 93-101. 
Raukas, A. \& Gaigalas, A., 1993. Pleistocene glacial deposits along the eastern periphery of the Scandinavian ice sheets - an overview. Boreas 22, 214-222.

Raukas, A. \& Tavast, E., 1987. Eesti mattunud orgude ehitusest. [On the structure of buried valleys in Estonia]. Eesti Geograafia Seltsi aastaraamat 1981/1982 20, 5-15 [in Estonian with Russian and English summaries].

Raukas, A., Koch, R., Jüriado, K. \& Järvelill, I.J., 2014. Anomalous radioactivity level and high concentrations of heavy minerals in Lemme area, South-West Estonia. Baltica 27, 2, 93-103.

Stankowski, W. (Ed.), 1976. Till, its genesis and diagenesis. Uniwersitet im. Adama Mickiewicza w Poznaniu. Seria Geografia 12, 266 pp.

Suuroja, K., 2006. Põhja-Eesti klint - Eesti looduse sümbol [North-Estonian Klint - Symbol of Estonian nature]. Keskkonnaministeerium, Tallinn, 224 pp. [in Estonian].

UNSCEAR, 1993. United Nations Scientific Committee on the Effects of Atomic Radiation. Report to the General Assemb- ly, with scientific annexes. United Nations, New York, 922 pp.

Vaher, R., Miidel, A., Raukas, A. \& Tavast, E., 2010. Ancient buried valleys in the city of Tallinn and adjacent area. Estonian Journal of Earth Sciences 59, 37-48.

Vares, K. \& Raukas, A., 1981. The Estonian soil-forming rocks. Eesti NSV Teaduste Akadeemia Toimetised. Geoloogia 30, 125-132 [in Russian with English and Estonian summaries].

Wedepohl, K.H., 1995. The composition of the continental crust. Geochimica et Cosmochimica Acta 59, 1217-1232.

World Health Organization (WHO), 2009. WHO handbook on indoor radon: a public health perspective. WHO, Geneva, $94 \mathrm{pp}$.

Manuscript submitted 15 January 2015 Revision accepted 25 April 2015 